\title{
Nicotine dependence and psychological distress: outcomes and clinical implications in smoking cessation
}

This article was published in the following Dove Press journal:

Psychology Research and Behavior Management

9 September 201 I

Number of times this article has been viewed

\section{Fiammetta Cosci' \\ Francesco Pistelli ${ }^{2}$ \\ Nicola Lazzarini' \\ Laura Carrozzi}

'Department of Psychology, University of Florence, Florence; ${ }^{2}$ University Unit of Pulmonology and Respiratory Pathophysiology, Cardiothoracic Department, University Hospital of Pisa, Pisa, Italy
Correspondence: Fiammetta Cosci Department of Psychology, University of Florence, via di San Salvi I2, 50I 35 Florence, Italy

Tel + $39055623781 \mathrm{I}$

$\mathrm{Fax}+390556236047$

Email fiammetta.cosci@unifi.it
Abstract: Nicotine dependence is characteristically a chronic and relapsing disease. Although $75 \%-85 \%$ of smokers would like to quit, and one-third make at least three serious lifetime attempts, less than $50 \%$ of smokers succeed in stopping before the age of 60 . Relevant and complex factors contributing to sustained cigarette consumption, and strongly implicated in the clinical management of smokers, are the level of nicotine dependence and psychological distress. In this review of the literature, these two factors will be examined in detail to show how they may affect smoking cessation outcome and to encourage clinicians to assess patients so they can offer tailored support in quitting smoking.

Keywords: nicotine dependence, psychological distress, quitting, smoking cessation, clinical management

\section{Introduction}

In 1980, the diagnosis of "nicotine dependence" was for the first time included in the third edition of the Diagnostic and Statistical Manual of Mental Disorders (DSM). Eight years later, the US Surgeon General published a seminal report entitled "The health consequences of smoking: nicotine and addiction," "1 where tobacco smoking was defined as an addiction. Current criteria for the diagnosis of nicotine dependence are defined by the American Psychiatric Association in the DSM fourth edition-text revised $(\mathrm{DSM}-\mathrm{IV}-\mathrm{TR})^{2}$ and by the World Health Organization (WHO) in the International Classification of Diseases, 10th revision (IDC-10). ${ }^{3}$

The prevalence of nicotine dependence in the general population is about $13 \%$, constituting nearly half of current nicotine users. ${ }^{4}$ Since the vast majority of smokers smoke for most of their life, alternating periods of remission and relapse, nicotine dependence is currently widely recognised as a chronic and relapsing disease. ${ }^{5}$ Although $75 \%-85 \%$ of smokers would like to stop, several attempts are usually needed before quitting definitively and less than $50 \%$ of smokers succeed in stopping permanently before the age of $60 .{ }^{6}$

Although pharmacological and nonpharmacological interventions are effective in treating nicotine dependence, there is a growing interest in identifying the factors that may influence smoking cessation and relapse. Among others, the psychoactive effects of nicotine, associative learning processes, environmental culture (including access to and availability of tobacco products, acceptability, and parental or peer modeling), individual characteristics (ie, genetic and personality features), ${ }^{7}$ and heritability (twin studies suggest a genetic contribution of about $50 \%$ in the prevalence of cigarette smoking, the ability to quit smoking, and the number of cigarettes smoked per day $)^{8}$ seem to contribute to starting and sustaining cigarette consumption. However, nicotine 
dependence and the psychological distress experienced while quitting are widely recognized as particularly relevant predictors of smoking cessation.

This review describes these two constructs in detail, shows how they may affect smoking cessation outcome, and highlights the importance of assessing both nicotine dependence and psychological distress when assisting smoking patients, in order to provide tailored support during the smoking cessation process.

\section{Management of nicotine dependence}

Current evidence-based guidelines for the treatment of nicotine dependence recommend using pharmacotherapy in conjunction with counseling. ${ }^{5}$ However other factors, which will be briefly described below, may have clinical implications that need to be taken into account when assisting a smoker in quitting.

\section{Smokers' socio-demographic characteristics}

The association between smoking and low socioeconomic status (SES) has become stronger in almost all industrialized countries ${ }^{9-13}$ despite the introduction of anti-tobacco interventions. ${ }^{14,15}$

A growing literature is focused on the role of sociodemographic variables as factors influencing the probability of quitting. Quitting smoking seems more likely among better-educated subjects, ${ }^{16-19}$ less disadvantaged socioeconomic groups, ${ }^{17-20}$ older individuals,,${ }^{19,21}$ and users living with a spouse or partner. ${ }^{18-20}$

A possible explanation of these results is that bettereducated individuals seem to be more responsive to messages about the adverse consequences of smoking compared with poorly-educated ones. Moreover, lower-SES smokers seem to have a lower level of social support and confidence in their ability to quit. ${ }^{22}$ Finally, lower-SES women often perceive smoking as an effective strategy for coping with stress and difficult living circumstances. ${ }^{23,24}$

Older people have higher success rates due to their greater likelihood of adhering to a treatment program, smaller risk of relapse, and a higher incidence of tobacco-related health problems. ${ }^{25}$

When marital status is considered, quitting seems to be an easier task for married than for nonmarried subjects. The literature suggests that married subjects, especially men, have an overall better adherence to treatments. ${ }^{26,27}$

\section{Pathophysiology of nicotine dependence}

Inhaled nicotine reaches the brain rapidly, about 10-20 seconds after a puff, and has an elimination half-life in chronic smokers of about 2 hours. As a consequence, nicotine blood levels are stable only if subjects smoke frequently. ${ }^{28}$

Nicotine stimulates the central nicotinic cholinergic receptors inducing the release of several neurotransmitters in the brain. Dopamine, mainly produced in the ventral tegmental area and in the nucleus accumbens, is of particular importance since it provokes a pleasurable experience which promotes the reinforcing self-administration of nicotine. Other neurotransmitters, including norepinephrine, acetylcholine, serotonin, $\gamma$-aminobutyric acid (GABA), glutamate, and endorphins lead to the arousal, mood modulation, performance enhancement, analgesic, and weight-loss effects associated with smoking.

With repeated exposure to nicotine, neuroadaptation (tolerance) develops ${ }^{29}$ while nicotine-mediated desensitization of receptors leads to upregulation of receptors in the brain. Chronic smokers experience symptoms of craving and withdrawal when desensitized nicotinic receptors become newly responsive during periods of abstinence, such as night-time sleep. Thus, smokers modulate their smoking habit throughout the day to maintain nicotine plasma levels high enough to prevent the occurrence of withdrawal symptoms over the night or over the nonsmoking period. Moreover, conditioned smoking cues tend to maintain smoking behavior during the periods of saturation and desensitization of nicotinic brain receptors. ${ }^{29}$ Over time, associative learning between stimuli in the environment (eg, specific moods, situations) and the positive rewarding effects of nicotine and withdrawal symptoms might occur. Cues begin to control behavior, evoking craving for the drug or drug-seeking behavior (for example, lighting a cigarette after finishing a meal).

The treatment of nicotine dependence should take into account the clinical implications due to the combination of positive reinforcement, such as enhancement of mood or decrease of withdrawal symptoms, along with conditioning. Drugs for smoking cessation act primarily on the control of withdrawal symptoms but do not replace the positive and pleasant effects of smoking. Behavioral counseling should help smokers to cope with conditioning. A strong dose-response relationship between counseling intensity (length and number of treatment sessions) and quitting success has been observed. ${ }^{5}$

\section{Motivation to quit smoking}

Quitting smoking leads to loss of the positive and pleasant effects of nicotine and produces the negative symptoms of 
nicotine withdrawal. In addition, there is an important impact on the daily habits of the abstinent smoker since smoking is associated with a variety of learned and social behaviors. For these reasons, nicotine dependence can be viewed as a state in which the personal cost of quitting can be extremely high (ie, too uncomfortable or impairing personal functioning too greatly). ${ }^{30}$ Whether a smoker succeeds in quitting depends on the balance between that individual's motivation to stop smoking (ie, expected benefits of smoking cessation) and the degree of nicotine dependence.

According to the trans theoretical model, ${ }^{31}$ smokers who prepare their attempts to stop well in advance increase their chances of success. ${ }^{32}$ Thus, in an assisted smoking-cessation program the motivation to quit should be the prerequisite to engage in a smoking cessation attempt. However, in smokers suffering from smoking-related diseases, for whom quitting is a priority, a more interventional approach, aimed at least at smoking reduction, has been suggested. ${ }^{33} \mathrm{~A}$ meta-analysis based on results from randomized controlled clinical trials on motivational interviewing for smoking cessation vs brief advice or usual care yielded a modest but significant increase in quitting rates. ${ }^{34}$

Smokers' motives for quitting seem also to reflect a social unacceptability of smoking which has been buttressed by measures intended to reduce tobacco use. For instance, by alerting people to the dangers of second-hand smoke, health campaigns might be responsible for smokers feeling uncomfortable about smoking in public. ${ }^{35,36}$ Moreover, nonsmokers may tend to see smokers as drug addicts whose habit threatens their health and that of others. ${ }^{37}$ International literature reports evidence that the denormalization of smoking is an effective component of measures intended to reduce tobacco use. ${ }^{35,36,38}$ For instance, a longitudinal study assessing data from Canada, USA, UK, and Australia concluded that smokers are more likely to intend to quit and to be abstinent at follow-up when they have important social denormalization beliefs about smoking, such as feeling disapproved of for smoking, being uncomfortable about smoking in public, and being advised to quit by people close to them. ${ }^{36}$

Motivation seems also strictly linked to the perception of self. For instance, most teenagers regard themselves as smokers but few think they are addicted and, although many are interested in quitting, they usually do not consider this a priority. ${ }^{39}$ The barriers to quitting frequently revolve, at least in teenagers, around social image. Smoking is viewed as a social behavior and an important mechanism for sustaining and reinforcing social bonds. Being with smoking friends reinforces smoking and has a negative impact on attempts to quit. Thus, this subgroup of smokers seem to be reluctant to take up traditional cessation services and rather need to be grounded in their understanding of smoking and the social factors which support smoking in addition to being helped to understand how support may increase quitting success. ${ }^{39}$

\section{Response to pharmacotherapy}

Despite pharmacological treatments that have been found effective in controlled clinical trials, estimated abstinence rates at 6 months range from $19 \%$ to $33 \%$ depending on the drug used, ${ }^{5}$ and are expected to be lower in unselected populations (ie, real life situations).

Large inter-individual variability in drug response may be caused by low adherence to the treatment, drug interactions, changes in the rate of nicotine metabolism and the smoker's genetic make-up. Adherence to pharmacotherapy for smoking cessation has been demonstrated to be highly correlated with improved tobacco abstinence. ${ }^{40}$ Drug interaction is a preventable cause of inter-individual variability in nicotine metabolism. CYP2A6-metabolized drugs may affect nicotine pharmacokinetics and efficacy of nicotine replacement therapy. ${ }^{8}$ Changes in nicotine metabolism may depend on physiological influences (such as age and gender) and pathological conditions (eg, CYP2A6 activity is reduced in patients with alcoholic liver disease and viral hepatitis) ${ }^{28}$ Finally, the pharmacotherapy of smoking cessation is affected by the interplay of several gene products that influence the pharmacokinetics and pharmacodynamics of medications, including inherited differences in drug targets (eg, nicotine and dopamine receptor subtypes) and drug disposition (eg, metabolizing enzymes including CYP2A6 and CYP2B6). ${ }^{41}$ Variants in the dopamine $\mathrm{D} 2$ receptor have been reported to affect response to transdermal nicotine and/or bupropion. Variation in the opiate mu 1 receptor gene seems to influence response to transdermal nicotine, and variants in the CYP2B6 gene have been found to predict response to bupropion. ${ }^{8}$ Genetically low metabolizers (including people with variant CYP2A6 genes associated with substantially reduced enzyme activity) smoke on average fewer cigarettes per day, appear to be less dependent, and are more likely to quit. ${ }^{8}$

An algorithm and guide based on the opinion of experts in tobacco cessation has been recently developed ${ }^{42}$ and genetic variations to be considered in order to personalize nicotine dependence pharmacotherapy have been discussed. ${ }^{41}$

\section{Psychiatric comorbidity}

According to population-based data, more than $40 \%$ of smokers report a current psychiatric disorder and $60 \%$ a lifetime 
one. ${ }^{43}$ Nicotine may serve to medicate some psychiatric symptoms. ${ }^{8}$ For example, since smoking inhibits monoamine oxidases, the release of serotonin and norepinephrine induced by nicotine is similar to the one occurring under treatment with monoamine oxidase inhibitor antidepressants.

Based on results from meta-analyses, the therapies effective in treating nicotine dependence in the general population also work in patients with severe mental illnesses and do not worsen their mental state if they have stable psychiatric conditions. ${ }^{44}$

In this framework, the presence of psychiatric comorbidity should always be assessed when treating nicotine dependence, because of its implications in the psychological or pharmacological support needed to complement the assisted smoking cessation program.

\section{Treatment of nicotine dependence}

Treatment is targeted towards dealing with physical addiction to nicotine, psychological reliance on the effects of nicotine, and behavioral aspects of tobacco use. Several pharmacological and nonpharmacological interventions are effective in treating nicotine dependence and evidence-based guidelines have been developed. ${ }^{5}$

Nonpharmacological approaches include educational, motivational, or behavioral interventions and may be tailored to different populations. In general, intensive support increases the likelihood of quitting; for instance, the 3\%-5\% 1 -year spontaneous quit rate improves to $7.5 \%$ with brief physician advice. ${ }^{45}$ Similarly, behavioral support increases quit rates when it is given via telephone quit lines, ${ }^{46}$ or group ${ }^{47}$ or individual counseling. ${ }^{48}$ Finally, a combination of counseling and medication is more effective for smoking cessation than either medication or counseling alone. ${ }^{5}$

Pharmacological aids are recommended for all smokers trying to quit, except when medically contraindicated or in cases where there is insufficient evidence of effectiveness (eg, pregnant women, smokeless tobacco users, light smokers, adolescents). ${ }^{5}$ They are currently classified as first-line (bupropion, nicotine, varenicline) and second-line medications (nortriptyline, clonidine). ${ }^{5}$ First-line medications are safe and effective and have been approved by the US Food and Drug Administration (FDA) for the treatment of nicotine dependence. Weaker evidence of efficacy has been found for the second-line medications. Several concerns still exist about their side effects and they have not yet received FDA approval as treatments for nicotine dependence (mechanisms of action, common side effects, and cautions are reported in Table 1).
In clinical trials, nicotine replacement therapy and bupropion approximately double quit rates, ${ }^{49,50}$ whereas varenicline increases quit rates by three-fold over those achieved with placebo. ${ }^{51}$ Looking at second-line drugs, nortriptyline doubles the odds of quitting. ${ }^{50}$ Clonidine, although associated with increased smoking cessation, shows lower odds. ${ }^{52}$

Although pharmacotherapies are able to improve success rates, the probability of maintaining abstinence 1 year after smoking cessation still remains fairly low (overall 20\%). ${ }^{45}$ For this reason, new drugs are being tested..$^{53}$ The first is the nicotine vaccine, which stimulates the immune system to develop anti-nicotine antibodies. Preliminary studies in humans show that it is safe and well tolerated. ${ }^{54}$ Another interesting drug is a selective cannabinoid $\mathrm{CB} 1$ receptor antagonist, rimonabant, which restores the balance of the endocannabinoid system. It increases the chance of quitting by approximately 1.5 -fold, but evidence on its capacity to maintain abstinence is still inconclusive. Further cannabinoid receptor antagonists are under study. ${ }^{55}$

Pharmacotherapies appear effective and cost-effective, however research on their appropriate use in unselected populations (ie, different from those usually participating in randomized clinical trials) is warranted to increase their applicability and effectiveness in daily clinical practice. ${ }^{53}$ Similarly, further research is needed to find treatments effective in specific subpopulations of smokers. For instance, in the past, it was suggested that subjects high in pretreatment negative affect respond best to support counseling; those low in pretreatment negative affect respond best to skills training; while self-reports of pretreatment craving predicted response to the nicotine replacement treatment. ${ }^{56}$

\section{Psychological distress as a predictor of smoking cessation}

Psychological distress is a nonspecific dimension which refers both to symptoms and also to normal emotional responses to adversity. It encompasses sadness, frustration, anxiety, and a number of other negative mood states, such as hopelessness, nervousness, and depressive mood. Psychological distress can range from mild to severe and from transient to persistent. ${ }^{57}$ Healthy subjects facing changes in their life ${ }^{58}$ as well as patients with organic or psychiatric disorders may experience it, ${ }^{59,60}$ as can smokers at the initiation, maintenance, quitting, or relapse stages. ${ }^{61}$

Affective states, such as irritability, anxiety, and depression, might be due either to the fact that the subject is facing a challenge such as quitting smoking, or to nicotine interruption. For this reason, a careful differential diagnosis should be 
Table I Pharmacotherapies for nicotine dependence

\begin{tabular}{|c|c|c|c|}
\hline & $\begin{array}{l}\text { Site of action/ } \\
\text { mechanisms of action }\end{array}$ & Side effects & Cautions \\
\hline \multicolumn{4}{|l|}{ First-line therapies } \\
\hline $\begin{array}{l}\text { Nicotine replacement therapy } \\
\text { (patch, gum, inhaler, nasal } \\
\text { spray, lozenge, microtab) }\end{array}$ & $\begin{array}{l}\text { Receptor stimulation/agonist } \\
\text { of nicotine receptors, nicotine } \\
\text { substitution }\end{array}$ & $\begin{array}{l}\text { Localized irritation: skin } \\
\text { irritation (patch); mouth } \\
\text { and throat irritation } \\
\text { (oral preparations) }\end{array}$ & $\begin{array}{l}\text { Recent myocardial infarction, } \\
\text { serious arrhythmias, unstable } \\
\text { angina pectoris; hyperthyroidism, } \\
\text { pheochromocytoma; } \\
\text { uncontrolled hypertension; } \\
\text { peptic ulcers; allergy to tape } \\
\text { or dermatological conditions }\end{array}$ \\
\hline Varenicline & $\begin{array}{l}\text { Receptor stimulation } / \alpha 4 \beta 2 \\
\text { neuronal nicotinic cholinergic } \\
\text { receptors partial agonist }\end{array}$ & $\begin{array}{l}\text { Nausea, headache, abnormal } \\
\text { dreams }\end{array}$ & $\begin{array}{l}\text { Severe renal impairment; } \\
\text { history/presence of major } \\
\text { depression; impair ability } \\
\text { to drive; pregnancy }\end{array}$ \\
\hline Sustained-release bupropion & $\begin{array}{l}\text { Dopamine transporter/inhibition } \\
\text { of neuronal re-uptake } \\
\text { of noradrenaline and dopamine, } \\
\text { with minimal effect on the } \\
\text { re-uptake of serotonin }\end{array}$ & $\begin{array}{l}\text { Insomnia, dry mouth, } \\
\text { headache }\end{array}$ & $\begin{array}{l}\text { Seizure disorders; bulimia } \\
\text { or anorexia nervosa, bipolar } \\
\text { disorder; severe hepatic } \\
\text { necrosis; concomitant/recent } \\
\text { use of monoamine oxidase } \\
\text { inhibitors }\end{array}$ \\
\hline \multicolumn{4}{|l|}{ Second-line therapies } \\
\hline Nortriptyline & $\begin{array}{l}\text { Serotonin transporter/serotonin } \\
\text { and noradrenalin re-uptake } \\
\text { inhibition }\end{array}$ & $\begin{array}{l}\text { Dry mouth, blurred vision, } \\
\text { constipation, urinary retention, } \\
\text { sedation, drowsiness, } \\
\text { weight gain, orthostatic } \\
\text { hypotension }\end{array}$ & $\begin{array}{l}\text { Cardiovascular disease; } \\
\text { pregnancy }\end{array}$ \\
\hline Clonidine & $\begin{array}{l}\text { Other nervous } \\
\text { pathways/ } \alpha 2 \text {-noradrenergic } \\
\text { agonist }\end{array}$ & $\begin{array}{l}\text { Dry mouth, drowsiness, } \\
\text { dizziness, sedation, constipation, } \\
\text { allergic reactions, bradycardia, } \\
\text { abnormally high or low blood } \\
\text { pressure }\end{array}$ & $\begin{array}{l}\text { Cardiovascular disease; } \\
\text { pregnancy }\end{array}$ \\
\hline \multicolumn{4}{|c|}{ Other therapies (not yet approved by the FDA) } \\
\hline Nicotine vaccine & $\begin{array}{l}\text { Nicotine absorption/active } \\
\text { immunization }\end{array}$ & $\begin{array}{l}\text { Injection site reaction, flu-like } \\
\text { symptoms, headache, myalgia }\end{array}$ & To be defined \\
\hline Rimonabant & $\begin{array}{l}\text { Other nervous pathways/selective } \\
\text { antagonist of cannabinoid } \\
\text { type I receptors }\end{array}$ & $\begin{array}{l}\text { Nausea, upper respiratory tract } \\
\text { infections }\end{array}$ & $\begin{array}{l}\text { Depression and suicidal } \\
\text { to be defined }\end{array}$ \\
\hline
\end{tabular}

always conducted in order to establish whether psychological distress is related to the real distress the subject is feeling during the cessation program or to the occurrence of nicotine withdrawal symptoms. This distinction can be achieved by carefully examining symptoms and signs that occur while quitting (for example, withdrawal symptoms tend to appear in the first week of cessation and usually last 2-4 weeks).

\section{Psychological distress}

Several studies investigated psychological distress as a general dimension in smokers. Dube et al analyzed data from 172,938 adult respondents in the 2007 Behavioral Risk Factor Surveillance System and observed that smokers and those attempting to quit had higher levels of psychological distress when compared to those who never smoked..$^{62}$ Lawrence et al examined, among participants in the 2005 United States
National Health Interview Survey (NHIS), the relationship between the outcome of smoking cessation attempts and psychological distress. They compared the answers given by recent successful quitters (ie, those who reported having quit smoking 7-24 months prior to the survey without relapses) with those by current smokers (ie, those who had unsuccessfully attempted to quit smoking in the previous 12 months). The rate of smoking increased with psychological distress (from $17.7 \%$ to $41.9 \%$ ) and subjects with high levels of psychological distress were more likely to be current smokers. Although they commonly had the intention to quit smoking and tried to do it, they had a significantly lower number of abstinence periods lasting at least 6 months. ${ }^{63}$

In a large Australian national household survey, current smokers with psychological distress were just as, or more likely, to report planning to quit as those without 
psychological distress. However, smokers who had past failure in quitting and smoked to feel relaxed or deal with stress were more likely to report psychological distress. ${ }^{64}$

Two clinical studies showed that increases in post-quit anger were associated with relapse 5 days ${ }^{65}$ and 28 days ${ }^{66}$ after quitting; however, in the second study, ${ }^{66}$ this effect was lost when other measures of craving and withdrawal were added to the model. Similarly, higher levels of hostility, tension, and depressive feelings have been associated with a higher risk of continuing smoking. ${ }^{67,68} \mathrm{~A}$ more recent study reported that those with high trait anger relapsed sooner than their low trait anger counterparts. ${ }^{69}$ Similarly, Patterson et al found that smokers with increased anger during the first week of treatment relapsed almost twice as quickly as those who did not have an increase in post-quit anger symptoms. Moreover, participants with increased post-quit anger symptoms took significantly fewer days to relapse compared to those who did not report increased post-quit anger symptoms (8 days vs 54 days, respectively). ${ }^{70}$

According to our study on 297 cigarette smokers followed for 1 year, high levels of psychological distress at 12 , 26 , and 52 weeks of follow-up affected long-term smoking cessation rates. A possible explanation of this phenomenon is that the psychological distress may have implied affective vulnerability, dysphoria, and negative affectivity, and therefore, weakened persistence in a stressful task such as quitting smoking. ${ }^{71}$

\section{Negative affectivity as a dimension of psychological distress}

Several studies have focused on a more specific psychological dimension contained in the broader construct of psychological distress, so-called "negative affectivity," which mainly refers to symptoms of depression and/or anxiety.

Prospective studies have shown that affective distress at the beginning of treatment ${ }^{72}$ and after quitting ${ }^{73,74}$ predicts poor outcome. Furthermore, in retrospective studies, smokers consistently report that relapse to smoking often occurs in situations involving negative moods such as anxiety, anger, and depression, ${ }^{75-78}$ and that smokers who smoke more frequently in negative affect situations are more likely to relapse. ${ }^{79}$ Moreover, Shiffman and Waters found that surges in negative affect often began a few hours before a smoking relapse occurred. ${ }^{80}$ Thus, it may be the responses to acute stressors and resulting rapidly increasing negative affect that are most relevant to relapse. Finally, changes in negative affectivity seem consistently related to the persistence of the urge to smoke. ${ }^{81}$
Interesting evidence emerges from studies conducted on smokers applying to smoking cessation clinics. Fakhfakh et $\mathrm{al}^{82}$ observed that $22.9 \%$ of them had depression, $20 \%$ anxiety, and $7.1 \%$ had symptoms of both anxiety and depression.

According to our experience, smokers who ask for a baseline evaluation at a smoking cessation facility report higher levels of negative affectivity than smokers from the general population, considering symptoms of both anxiety and depression. A possible explanation for this relationship might be that anxiety and depression can act as important motivators to quit. ${ }^{83}$

Further contributions come from longitudinal surveys. Shiffman et al compared reports of immediate experiences during random moments, highly tempting situations, and first relapses to smoking in a sample of quitters. A linear relationship was found between the type of assessment and negative affect ratings. First relapses were characterized by high negative affect, temptations involved somewhat less negative affect, and random moments were characterized by the lowest negative affect ratings. Moreover, approximately $20 \%$ of first relapses to smoking occurred at moments when negative affect was extremely high (approximately $2.5 \mathrm{SD}$ above the mean). ${ }^{84}$

Niaura and colleagues prospectively examined the ability of current symptoms of depression to predict failure to quit smoking in treatment-motivated smokers. Pretreatment depressed mood was assessed by three different methods in three separate samples, two of which comprised smokers receiving combined pharmacological and behavioral treatments and a third in which smokers received self-help materials only. Interestingly, even very low levels of depressive symptomatology at the outset of a smoking cessation attempt predicted dramatically lower long-term abstinence rates. ${ }^{85}$

Finally, Kahler et al examined the within-person covariation between smoking abstinence and depressive symptoms following a quitting attempt. Although in the first weeks all the subjects reported a slight increase of depressive symptoms, there was an inverse relationship between time-varying abstinence from smoking and concurrent level of depressive symptoms. This means that passing from smoking to abstinence was associated with a reduction in depressive symptoms. Subjects abstinent at all follow-up visits $(2,8$, 16,26 weeks) had lower levels of depressive symptoms as measured at baseline and maintained such levels throughout the follow-up observation. Smokers who relapsed showed the lowest levels of depressive symptoms when abstinent while those who continued to smoke had a gradual increase over 
time. ${ }^{86}$ Thus, according to this study, depressive symptoms may have a positive influence in pursuing a task such as quitting.

Different conclusions can be drawn when considering anxiety. In a longitudinal study conducted on 575 women and examining predictors of smoking cessation, high levels of anxiety significantly predicted subsequent quitting. Women more anxious at baseline were about three times more likely to report quitting 13 years later than women with low baseline anxiety. ${ }^{87}$

\section{Distress tolerance}

It has become increasingly clear that relapses to smoking may occur very early in many cessation attempts, ie, within hours or days after the quit day. For example, in studies of people who quit on their own, approximately one-third to one-half smoke within a few days and $50 \%-60 \%$ smoke within the first 2 weeks. ${ }^{88-90}$ Early relapse is also common among participants who receive smoking cessation treatments. In studies examining nicotine replacement strategies or group-based cessation intervention, $43 \%-50 \%$ of participants still smoked within the first week ${ }^{91}$ and most of the relapses occurred within the first few days. ${ }^{81,92}$ Not only are early relapses common, but the vast majority of smokers who experience them ultimately do not succeed in quitting. In studies following self-quitters and in those using nicotine replacement, it is estimated that more than $85 \%$ of participants who experienced an early relapse subsequently failed to quit. ${ }^{91,93}$

Emerging evidence suggests that it is not just the severity or intensity of nicotine withdrawal, but also how an individual responds to discomfort and distress that predicts early smoking relapses. In this framework, the term "distress tolerance" has been coined to convey a behavioral tendency to continue to pursue a goal despite encountering various states of affective discomfort, which may be in response to perceived physical and/or psychological distress. ${ }^{94}$

Whereas many smokers quit smoking successfully despite high levels of discomfort, it is likely that a low threshold for tolerating such unavoidable distress would be associated with increased difficulty in quitting. Brown et al studied current smokers who by quit attempt history were either immediate (ie, had never quit for more than 24 hours) or delayed relapsers (ie, had quit for at least 3 months) and assessed individuals' distress tolerance, as indexed by their persistence on psychological and physical challenge tasks. ${ }^{94}$ The results indicated that immediate relapsers were more likely to terminate the challenge tasks than delayed relapsers.
Baker and co-workers stressed the role of low psychological distress tolerance in favoring early relapses, hypothesizing that negative affect is the "motivational core" of the withdrawal syndrome. They suggested that when either stressors or abstinence cause negative affect to grow and enter consciousness, increasing negative affect biases information processing in ways that promote renewed drug administration. ${ }^{95}$ Brown et al agreed with this model and further posited that there are individual differences in how smokers respond to negative affect, and it is these responses in the face of negative affect that determine who relapses in a few days/hours and who maintains abstinence. ${ }^{96}$

\section{Patient-focused perspectives in quitting smoking}

The current Clinical Practice Guidelines ${ }^{5}$ recommend addressing patients' smoking at each visit using a fivestep strategy called the 5As: ask about tobacco use; advise smokers to quit; assess smokers' willingness to make a quit attempt; assist with treatment; arrange follow-up. Although some authors report concerns related to the overuse of tobacco cessation advice, ${ }^{97,98}$ Conroy et al demonstrated a strong association between the full range of $5 \mathrm{~A}$ tobacco counseling steps and satisfaction with overall health care as well as tobacco-related care. ${ }^{99}$

Advice, to be really effective, should be given within the framework of a good patient-clinician relationship, in which clinicians take into account patients' perspectives about treatment and smoking cessation. For instance, Butler et al reported that most subjects consider it good practice to use a respectful tone; sensitivity to the patient's receptivity; understanding the patient as an individual; being supportive; and not preaching. ${ }^{100}$ Moreover, it has been observed that advice/procedures offered regarding quitting may either enable or discourage the uptake of smoking cessation services in subjects sensible to the problem, such as pregnant women smokers. ${ }^{101}$

When smokers ask for help to quit, they also have a set of beliefs about the psychological benefits of smoking (eg, to cope with their negative affect), the health risks associated with smoking (eg, health risks are underestimated while the ability to minimize those risks is overemphasized), ${ }^{102}$ as well as the pros and cons of smoking cessation. During cessation attempts, they may change their beliefs, imagining less psychological benefits and more health threats due to smoking. These changes predict success in quitting: those who relapse report beliefs similar to current smokers with a decrease of their beliefs about the health risks of smoking. ${ }^{103}$ Thus, it seems 
appropriate to encourage such changes in the early stages of treatment as well as managing them in case of relapse, to prevent the impairment of future attempts to quit.

Patients' beliefs can also be modulated by the evidence of positive changes produced by smoking cessation. For instance, abstainers often have the perception of better functioning and well-being. In a longitudinal study comparing subjects randomly assigned to varenicline, bupropion, or placebo, those treated with active treatments (varenicline more than bupropion) had significantly improved health-related quality of life and selfcontrol compared with those who received placebo. ${ }^{39}$

The direct result of taking into account patients' perspective and beliefs in the framework of a proper clinician-patient relationship is adherence, the main ingredient for achieving treatment goals. In a study on pregnant smokers helped to quit with nicotine replacement therapy, adherence was a strong predictor of cessation. ${ }^{104}$ Similarly, in a study among Chinese smokers the quit rate in the adherent group was significantly greater $(40 \%)$ than that in the nonadherent one $(25 \%) .{ }^{105}$

\section{Conclusion}

Persistent cigarette consumption seems to be strongly influenced by two complex factors: nicotine dependence and psychological distress. While the level of nicotine dependence is commonly measured in smokers attending smoking cessation programs, the assessment of psychological distress is often neglected. However, such an evaluation should be performed, to get a complete picture of the smoker and offer a tailored intervention. Some patients, for instance, might benefit from psychological support aimed at managing psychological distress, a high level of negative affectivity, or a low psychological distress tolerance experienced while quitting.

The framework in which assessment, treatment, and advice should be delivered is a good patient-clinician relationship, which should take into account patients' perspectives, beliefs, and expectations about treatment and smoking cessation.

The desired outcome is to acquire the motivation to quit, and to adhere to treatment, which respectively provides the prerequisite for starting a smoking cessation attempt, and the main way to achieve treatment goals.

\section{Acknowledgments}

Dr Fiammetta Cosci wishes to thank her colleagues at the International College in Affective NeuroScience (ICANS) for their scientific support.

\section{Disclosure}

The authors report no conflicts of interest in this work.

\section{References}

1. US Department of Health and Human Services. The health consequences of smoking: nicotine addiction. A report of the Surgeon General. Rockville, MD: US Department of Health and Human Services; 1988.

2. American Psychiatric Association. Diagnostic and statistical manual of mental disorders, fourth edition, text revision (DSM-IV-TR). Washington, DC: American Psychiatric Association; 2000.

3. WHO. The ICD-10 classification of mental and behavioural disorders: diagnostic criteria for research. F10-F19. Available from: http://www. who.int/substance_abuse/terminology/ICD10ResearchDiagnosis.pdf. Accessed May 15, 2011.

4. Grant BF, Hasin DS, Chou SP, Stinson FS, Dawson DA. Nicotine dependence and psychiatric disorders in the United States: results from the national epidemiologic survey on alcohol and related conditions. Arch Gen Psychiatry. 2004;61(11):1107-1115.

5. Fiore MC, Jaén CR, Baker TB, et al. Treating Tobacco Use and Dependence: 2008 Update. Clinical Practice Guideline. Rockville, MD: US Department of Health and Human Services. Public Health Service; 2008.

6. WHO EMRO. Tobacco Free Initiative facts and FAQs. Available from: http://www.emro.who.int/tfi/facts.htm. Accessed May 15, 2011.

7. Hatsukami DK, Stead LF, Gupta PC. Tobacco addiction. Lancet. 2008;371(9629):2027-2038.

8. Benowitz NL. Pharmacology of nicotine: addiction, smokinginduced disease, and therapeutics. Annu Rev Pharmacol Toxicol. 2009; 49:57-71.

9. Cavelaars AE, Kunst AE, Geurts JJ, et al. Educational differences in smoking: international comparison. BMJ. 2000;320(7242):1102-1107.

10. Pierce JP, Fiore MC, Novotny TE, Hatziandreu EJ, Davis RM. Trends in cigarette smoking in the United States. Educational differences are increasing. JAMA. 1989;261(1):56-60.

11. Faggiano F, Versino E, Lemma P. Decennial trends of social differentials in smoking habits in Italy. Cancer Causes Control. 2001;12(7):665-671.

12. Schiaffino A, Fernandez E, Borrell C, Salto E, Garcia M, Borras JM. Gender and educational differences in smoking initiation rates in Spain from 1948 to 1992. Eur J Public Health. 2003;13(1):56-60.

13. Edwards R. The problem of tobacco smoking. BMJ. 2004;328 (7433):217-219.

14. Amos A. Women and smoking. Br Med Bull. 1996;52(1):74-89.

15. Mackenbach JP, Bakker MJ, Sihto M, Diderichsen F. Strategies to reduce socioeconomic inequalities in health. In: Bakker MJ, Mackenbach JP, editors. Reducing Inequalities in Health: A European Perspective. London and New York: Routledge; 2002:25-50.

16. Fernandez E, Garcia M, Schiaffino A, Borras JM, Nebot M, Segura A. Smoking initiation and cessation by gender and educational level in Catalonia, Spain. Prev Med. 2001;32(3):218-223.

17. Federico B, Costa G, Kunst AE. Educational inequalities in initiation, cessation, and prevalence of smoking among 3 Italian birth cohorts. Am J Public Health. 2007;97(5):838-845.

18. Leinsalu M, Kaposvári C, Kunst AE. Is income or employment a stronger predictor of smoking than education in economically less developed countries? A cross-sectional study in Hungary. BMC Public Health. 2011;11:97.

19. Ferguson J, Bauld L, Chesterman J, Judge K. The English smoking treatment services: one-year outcomes. Addiction. 2005;100 Suppl 2: 59-69.

20. Leinsalu M, Tekkel M, Kunst AE. Social determinants of ever initiating smoking differ from those of quitting: a cross-sectional study in Estonia. Eur J Public Health. 2007;17(6):572-578.

21. Wee LH, Shahab L, Bulgiba A, West R. Stop smoking clinics in Malaysia: characteristics of attendees and predictors of success. Addict Behav. 2011;36(4):400-403.

22. Osler M, Prescott E. Psychosocial, behavioural, and health determinants of successful smoking cessation: a longitudinal study of Danish adults. Tob Control. 1998;7(3):262-267. 
23. Graham H. Women's smoking and family health. Soc Sci Med. 1987;25(1):47-56.

24. Jefferis BJ, Power C, Graham H, Manor O. Changing social gradients in cigarette smoking and cessation over two decades of adult follow-up in a British birth cohort. J Public Health (Oxf). 2004;26(1): 13-18.

25. Godtfredsen NS, Prescott E, Osler M, Vestbo J. Predictors of smoking reduction and cessation in a cohort of Danish moderate and heavy smokers. Prev Med. 2001;33(1):46-52.

26. Broms U, Silventoinen K, Lahelma E, Koskenvuo M, Kaprio J. Smoking cessation by socioeconomic status and marital status: the contribution of smoking behavior and family background. Nicotine Tob Res. 2004;6(3):447-455.

27. Stephens MA, Rook KS, Franks MM, Khan C, Iida M. Spouses use of social control to improve diabetic patients' dietary adherence. Fam Syst Health. 2010;28(3):199-208.

28. Hukkanen J, Jacob P 3rd, Benowitz NL. Metabolism and disposition kinetics of nicotine. Pharmacol Rev. 2005;57(1):79-115.

29. Benowitz NL. Nicotine Addiction. N Engl J Med. 2010;362(24): 2295-2303.

30. Benowitz NL. Cigarette smoking and nicotine addiction. Med Clin North Am. 1992;76(2):415-437.

31. DiClemente CC, Prochaska JO, Fairhurst SK, Velicer WF, Velasquez MM, Rossi JS. The process of smoking cessation: an analysis of precontemplation, contemplation, and preparation stages of change. J Consult Clin Psychol. 1991;59(2):295-304.

32. West R, Sohal T. "Catastrophic" pathways to smoking cessation: findings from national survey. BMJ. 2006;332(7539):458-460.

33. Barbano G, Bressan MC, Nardini S. The stage-of-change model in smoking cessation in respiratory patients: does it need to be revisited? In: Nardini S, editor. Smoking Cessation. Sheffield, UK: European Respiratory Society Journals Ltd. 2008;42:51-56.

34. Lai DT, Cahill K, Qin Y, Tang JL. Motivational interviewing for smoking cessation. Cochrane Database Syst Rev. 2010;1:CD006936.

35. Biener L, Hamilton WL, Siegel M, Sullivan E. Individual, socialnormative, and policy predictors of smoking cessation: a multilevel longitudinal analysis. Am J Public Health. 2010;100(3):547-554.

36. Hammond D, Fong GT, Zanna MP, Thrasher JF, Borland R. Tobacco denormalization and industry beliefs among smokers from four countries. Am J Prev Med. 2006;31(3):225-232.

37. Chapman S, Freeman B. Markers of the denormalisation of smoking and the tobacco industry. Tob Control. 2008;17(1):25-31.

38. Albers AB, Siegel M, Cheng DM, Biener L, Rigotti NA. Effect of smoking regulations in local restaurants on smokers' antismoking attitudes and quitting behaviours. Tob Control. 2007;16(2):101-106.

39. Amos A, Wiltshire S, Haw S, McNeill A. Ambivalence and uncertainty: experiences of and attitudes towards addiction and smoking cessation in the mid-to-late teens. Health Educ Res. 2006;21(2):181-191.

40. Hays JT, Leischow SJ, Lawrence D, Lee TC. Adherence to treatment for tobacco dependence: association with smoking abstinence and predictors of adherence. Nicotine Tob Res. 2010;12(6):574-581.

41. Quaak M, van Schayck CP, Knaapen AM, van Schooten FJ. Implications of gene-drug interactions in smoking cessation for improving the prevention of chronic degenerative diseases. Mutat Res. 2009;667(1-2):44-57.

42. Bader P, McDonald P, Selby P. An algorithm for tailoring pharmacotherapy for smoking cessation: results from a Delphi panel of international experts. Tob Control. 2009;18(1):34-42.

43. Lasser K, Boyd JW, Woolhandler S, Himmelstein DU, McCormick D, Bor DH. Smoking and mental illness: a population-based prevalence study. JAMA. 2000;284(20):2606-2610.

44. Banham L, Gilbody S. Smoking cessation in severe mental illness: what works? Addiction. 2010;105(7):1176-1189.

45. LancasterT, Stead L. Physician advice for smoking cessation. Cochrane Database Syst Rev. 2004;4:CD000165.

46. Stead LF, Perera R, Lancaster T. Telephone counselling for smoking cessation. Cochrane Database Syst Rev. 2006;3:CD002850.
47. Stead LF, Lancaster T. Group behaviour therapy programmes for smoking cessation. Cochrane Database Syst Rev. 2005;2:CD001007.

48. Lancaster T, Stead LF. Individual behavioural counselling for smoking cessation. Cochrane Database Syst Rev. 2005;2:CD001292.

49. Stead LF, Perera R, Bullen C, Mant D, Lancaster T. Nicotine replacement therapy for smoking cessation. Cochrane Database Syst Rev. 2008; 1:CD000146.

50. Hughes JR, Stead LF, Lancaster T. Antidepressants for smoking cessation. Cochrane Database Syst Rev. 2007;1:CD000031.

51. Cahill K, Stead LF, Lancaster T. Nicotine receptor partial agonists for smoking cessation. Cochrane Database Syst Rev. 2011;2: CD006103.

52. Gourlay SG, Stead LF, Benowitz NL. Clonidine for smoking cessation. Cochrane Database Syst Rev. 2004;3:CD000058.

53. Carrozzi L, Pistelli F, Viegi G. Pharmacotherapy for smoking cessation. Ther Adv Respir Dis. 2008;2(5):301-317.

54. Hatsukami DK, Rennard S, Jorenby D, et al. Safety and immunogenicity of a nicotine conjiugate vaccine in current smokers. Clin Pharmacol Ther. 2005;78(5):456-467.

55. Chandler MA, Rennard SI. Smoking cessation. Chest. 2010; 137(2):428-435.

56. Zelman DC, Brandon TH, Jorenby DE, Baker TB. Measures of affect and nicotine dependence predict differential response to smoking cessation treatments. J Consult Clin Psychol. 1992;60(6):943-952.

57. Carney RM, Freedland KE. Psychological distress as a risk factor for stroke-related mortality. Stroke. 2002;33(1):5-6.

58. Ormel J, Wohlfarth T. How neuroticism, long-term difficulties, and life situation change influence psychological distress: a longitudinal model. J Pers Soc Psychol. 1991;60(5):744-755.

59. Pembroke TPI, Rasul F, Hart CL, Smith GD, Stansfeld SA. Psychological distress and chronic obstructive pulmonary disease in the Renfrew and Paisley (MIDSPAN) study. J Epidemiol Community Health. 2006;60(9):789-792.

60. Rasul F, Stansfeld SA, Hart CL, Gillis CR, Smith GD. Psychological distress, physical illness and mortality risk. J Psychosom Research. 2004;57(3):231-236.

61. Kassel JD, Stroud LR, Paronis CA. Smoking, stress, and negative affect: correlation, causation, and context across stages of smoking. Psychol Bull. 2003;129(2):270-304.

62. Dube SR, Caraballo RS, Dhingra SS, et al. The relationship between smoking status and serious psychological distress: findings from the 2007 Behavioral Risk Factor Surveillance System. Int J Public Health. 2009;54 Suppl 1:68-74.

63. Lawrence D, Mitrou F, Zubrick SR. Non-specific psychological distress, smoking status and smoking cessation: United States National Health Interview Survey 2005. BMC Public Health. 2011;11:256.

64. Leung J, Gartner C, Dobson A, Lucke J, Hall W. Psychological distress is associated with tobacco smoking and quitting behaviour in the Australian population: evidence from national cross-sectional surveys. Aust N Z J Psychiatry. 2011;45(2):170-178.

65. Perkins K, Grobe J, D’Amico D, Fonte C, Wilson A, Stiller R. Low-dose nicotine nasal spray use and effects during initial smoking cessation. Exp Clin Psychopharmacol. 1996;4(2):157-165.

66. Swan GE, Ward MM, Jack LM. Abstinence effects as predictors of 28-day relapse in smokers. Addict Behav. 1996;21(4):481-490.

67. Killen JD, Fortmann SP, Kraemer HC, Varady AN, Davis L, Newman B. Interactive effects of depression symptoms, nicotine dependence, and weight change on late smoking relapse. J Consult Clin Psychology. 1996;64(5):1060-1067.

68. Strasser AA, Kaufmann V, Jepson C, et al. Effects of different nicotine replacement therapies on postcessation psychological responses. Addict Behav. 2005;30(1):9-17.

69. al'Absi M, Carr SB, Bongard S. Anger and psychobiological changes during smoking abstinence and in response to acute stress: prediction of smoking relapse. Int J Psychophysiol. 2007;66(2):109-115.

70. Patterson F, Kerrin K, Wileyto EP, Lerman C. Increase in anger symptoms after smoking cessation predicts relapse. Drug Alcohol Depend. 2008;95(1-2):173-176. 
71. Cosci F, Corlando A, Fornai E, Pistelli F, Paoletti P, Carrozzi L. Nicotine dependence, psychological distress and personality traits as possible predictors of smoking cessation. Results of a double-blind study with nicotine patch. Addict Behav. 2009;34(1):28-35.

72. Kinnunen T, Doherty K, Militello FS, Garvey AJ. Depression and smoking cessation: Characteristics of depressed smokers and effects of nicotine dependence. J Consult Clin Psychol. 1996;64(4):791-798.

73. Covey LS, Glassman AH, Stetner F. Depression and depressive symptoms in smoking cessation. Compr Psychiatry. 1990;31(4):350-354.

74. Ginsberg D, Hall SM, Reus VI, Muñoz RF. Mood and depression diagnosis in smoking cessation. Exp Clin Psychopharmacol. 1995;3(4):389-395.

75. Bliss RE, Garvey AJ, Heinold JW, Hitchcock JL. The influence of situation and coping on relapse crisis outcomes after smoking cessation. $J$ Consult Clin Psychol. 1989;57(3):443-449.

76. Brandon TH, Tiffany ST, Obremski KM, Baker TB. Postcessation cigarette use: the process of relapse. Addict Behav. 1990;15(2):105-114.

77. Marlatt GA, Gordon JR, editors. Relapse prevention: Maintenance strategies in the treatment of addictive behaviors. New York: Guilford Press; 1985.

78. Shiffman S. Relapse following smoking cessation: A situational analysis. J Consult Clin Psychol. 1982;50(1):71-86.

79. Abrams DB, Monti PM, Pinto RP, Elder JP, Brown RA, Jacobus SI. Psychosocial stress and coping in smokers who relapse or quit. Health Psychology. 1987;6(4):289-303.

80. Shiffman S, Waters AJ. Negative affect and smoking lapses: A prospective analysis. J Consult Clin Psychol. 2004;72(2):192-201.

81. Doherty K, Kinnunen T, Militello FS, Garvey AJ. Urges to smoke during the first month of abstinence: Relationship to relapse and predictors. Psychopharmacology. 1995;119(2):171-178.

82. Fakhfakh R, Aouina H, Gharbi L, et al. Dependence tabagique et troubles anxio-depressifs chez le fumeur tunisien [Smoking dependence and symptoms of anxiety and depression among Tunisian smokers]. Rev Mal Respir. 2003;20(6 Pt 1):850-857.

83. Cosci F, Schruers KR, Pistelli F, Griez EJ. Negative affectivity in smokers applying to smoking cessation clinics: a case-control study. Depress Anxiety. 2009;26(9):824-830.

84. Shiffman S, Hickcox M, Paty JA, Gnys M, Kassel JD, Richards TJ. Progression from a smoking lapse to relapse: prediction from abstinence violation effects, nicotine dependence, and lapse characteristics. J Consult Clin Psychol. 1996;64(5):993-1002.

85. Niaura R, Britt DM, Shadel WG, Goldstein M, Abrams DB, Brown R. Symptoms of depression and survival experience among three samples of smokers trying to quit. Psychol Addict Behav. 2001;15(1):13-17.

86. Kahler CW, Spillane NS, Busch AM, Leventhal AM. Time-varying smoking abstinence predicts lower depressive symptoms following smoking cessation treatment. Nicotine Tob Res. 2011;13(2):146-150.

87. McGee R, Williams S. Predictors of persistent smoking and quitting among women smokers. Addict Behav. 2006;31(9):1711-1715.

88. Garvey AJ, Bliss RE, Hitchcock JL, Heinold JW, Rosner B. Predictors of smoking relapse among selfquitters: A report from the Normative Aging Study. Addict Behav. 1992;17(4):367-377.

89. Gulliver SB, Hughes JR, Solomon LJ, Dey AN. An investigation of self-efficacy, partner support and daily stresses as predictors of relapse to smoking in self-quitters. Addiction. 1995;90(6):767-772.
90. Ward KD, Klesges RC, Zbikowski SM, Bliss RE, Garvey AJ. Gender differences in the outcome of an unaided smoking cessation attempt. Addict Behav. 1997;22(4):521-533.

91. Schneider NG, Olmstead R, Nilsson F, Mody FV, Franzon M, Doan K. Efficacy of a nicotine inhaler in smoking cessation: A double-blind, placebo-controlled trial. Addiction. 1996;91(9):1293-1306.

92. Shiffman S, Balabanis MH, Paty JA, et al. Dynamic effects of self-efficacy on smoking lapse and relapse. Health Psychol. 2000; 19(4):315-323.

93. Kenford SL, Fiore MC, Jorenby DE, Smith SS, Wetter D, Baker TB. Predicting smoking cessation. Who will quit with and without the nicotine patch. JAMA. 1994;271(8):589-594.

94. Brown RA, Lejuez CW, Kahler CW, Strong DR. Distress tolerance and duration of past smoking cessation attempts. J Abnorm Psychol. 2002;1111(1):180-185.

95. Baker TB, Piper ME, McCarthy DE, Majeskie MR, Fiore MC. Addiction motivation reformulated: an affective processing model of negative reinforcement. Psychol Rev. 2004;111(1):33-51.

96. Brown RA, Lejuez CW, Kahler CW, Strong DR, Zvolensky MJ. Distress tolerance and early smoking lapse. Clin Psychol Rev. 2005;25(6):713-733.

97. Kottke TE, Solberg LI, Brekke ML. Initiation and maintenance of patient behavioral change: What is the role of the physician? J Gen Int Med. 1990;5 Suppl 5:S62-S67.

98. Ockene IS, Ockene JK. Barriers to lifestyle change, and the need to develop an integrated approach to prevention. Cardiol Clin. 1996;14(1):159-169.

99. Conroy MB, Majchrzak NE, Regan S, Silverman CB, Schneider LI, Rigotti NA. The association between patient-reported receipt of tobacco intervention at a primary care visit and smokers' satisfaction with their health care. Nicotine Tob Res. 2005;7 Suppl 1: S29-S34.

100. Butler CC, Pill R, Stott NC. Qualitative study of patients' perceptions of doctors' advice to quit smoking: implications for opportunistic health promotion. BMJ. 1998;316(7148):1878-1881.

101. Baxter S, Everson-Hock E, Messina J, Guillaume L, Burrows J, Goyder E. Factors relating to the uptake of interventions for smoking cessation among pregnant women: A systematic review and qualitative synthesis. Nicotine Tob Res. 2010;12(7):685-694.

102. Weinstein ND, Marcus SE, Moser RP. Smokers' unrealistic optimism about their risk. Tob Control. 2005;14(1):55-59.

103. Chassin L, Presson CC, Sherman SJ, Kim K. Long-term psychological sequelae of smoking cessation and relapse. Health Psychol. 2002;21(5):438-443.

104. Fish LJ, Peterson BL, Namenek Brouwer RJ, et al. Adherence to nicotine replacement therapy among pregnant smokers. Nicotine Tob Res. 2009;11(5):514-518.

105. Lam TH, Abdullah AS, Chan SS, Hedley AJ. Hong Kong Council on Smoking and Health Smoking Cessation Health Centre (SCHC) Steering Group. Adherence to nicotine replacement therapy versus quitting smoking among Chinese smokers: a preliminary investigation. Psychopharmacology (Berl). 2005;177(4):400-408.
Psychology Research and Behavior Management

\section{Publish your work in this journal}

Psychology Research and Behavior Management is an international, peerreviewed, open access journal focusing on the science of psychology and its application in behavior management to develop improved outcomes in the clinical, educational, sports and business arenas. Specific topics covered include: Neuroscience, memory \& decision making; Behavior

\section{Dovepress}

modification \& management; Clinical applications; Business \& sports performance management; Social and developmental studies; Animal studies. The manuscript management system is completely online and includes a quick and fair peer-review system. Visit http://www.dovepress. com/testimonials.php to read real quotes from published authors. 